\title{
The Impact of Using Social Media in Crisis Management According to Employees Perspectives
}

\section{Ali Mohammad Al Jaberi, Farid Qawasmeh}

To Link this Article: http://dx.doi.org/10.6007/IJARBSS/v10-i11/8130

DOI:10.6007/IJARBSS/v10-i11/8130

Received: 01 September 2020, Revised: 22 September 2020, Accepted: 13 October 2020

Published Online: 25 November 2020

In-Text Citation: (Al Jaberi, \& Qawasmeh, 2020)

To Cite this Article: Al Jaberi, A. M., \& Qawasmeh, F. (2020). The Impact of Using Social Media in Crisis Management According to Employees Perspectives. International Journal of Academic Research in Business and Social Sciences. 10(11), 628-644.

\section{Copyright: (c) 2020 The Author(s)}

Published by Human Resource Management Academic Research Society (www.hrmars.com)

This article is published under the Creative Commons Attribution (CC BY 4.0) license. Anyone may reproduce, distribute, translate and create derivative works of this article (for both commercial and non-commercial purposes), subject to full attribution to the original publication and authors. The full terms of this license may be seen

at: http://creativecommons.org/licences/by/4.0/legalcode

$$
\text { Vol. 10, No. 11, 2020, Pg. } 628 \text { - } 644
$$

Full Terms \& Conditions of access and use can be found at http://hrmars.com/index.php/pages/detail/publication-ethics 


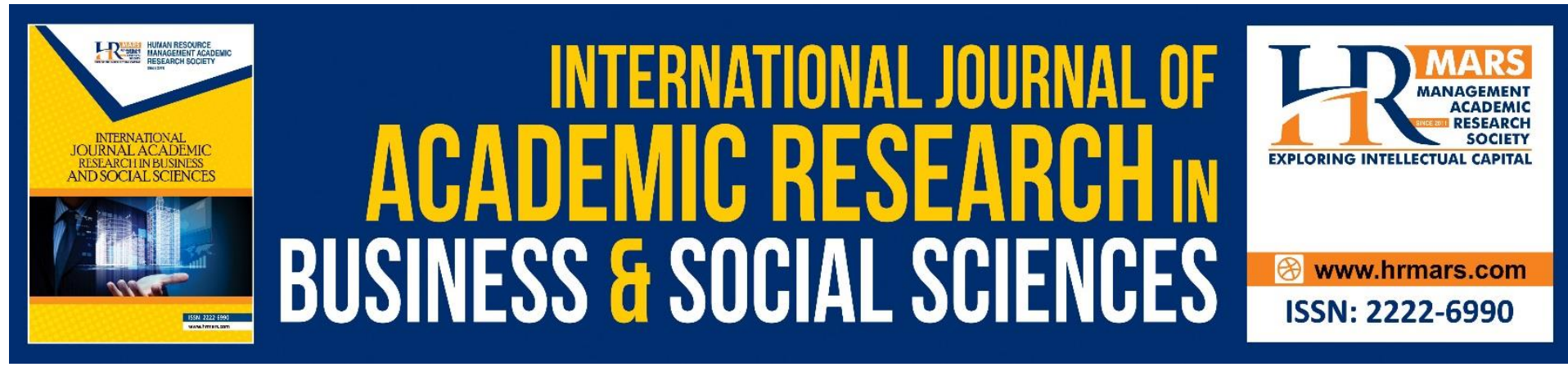

\title{
The Impact of Using Social Media in Crisis Management According to Employees Perspectives
}

\author{
Ali Mohammad Al Jaberi, Dr Farid Qawasmeh \\ cDepartment of Business Administration -Business Collage- JADARA University, Jordan
}

\begin{abstract}
This study is aimed at knowing the impact of using social networking sites in crisis management from the viewpoint of workers in the National Authority for Emergency, Crisis and Disaster Management in the United Arab Emirates. The researcher used the descriptive analytical approach, and the study population may be among the employees in the National Authority for Emergency, Crisis and Disaster Management (750) employees. A simple random sample of employees at different administrative levels was chosen, where the study found a statistically significant presence for the use of social media (Information dissemination, access to information, communication with others, privacy and security) in crisis management at the National Authority for Management Emergencies, crises and disasters in the United Arab Emirates. Accordingly, the study recommended increasing the activation of the use of social networks in the search for the necessary information that the authority needs, besides conducting an environmental survey (The external environment and the internal environment) periodically and regularly, so as to identify the indicators of the occurrence of crises. Hence, certain methods (Scenarios) were used to prepare pre-solutions to face the expected crisis.
\end{abstract}

Keywords: Social Media, Crisis Management, National Emergency Crisis and Disasters Management Authority, United Arab Emirates.

\section{Introduction}

The radical development of information and communication technology paved the way for the application and the use of social media. Meanwhile, many others believe that it is a growing phenomenon in the expansion of events and information connected to networks and connected to the library and information services. The Oxford Dictionary (2014) refers to social media as sites and applications on the web that enable users to create and share content or share in social networks. In addition, social media is also seen as a collection of websites, services, and online practices that support community building and participation. According to Kaplan and Haenlein (2010), social media uses mobile and web technologies to create highly interactive platforms through which communities including individuals, and hence, create, share, and discuss, besides modifying user generated content. Social media includes many sources, online information that is created, traded, and used by individuals, groups and organizations to educate each other about the products, services and brands 
available in the market. Furthermore, social media is a communication mechanism that allows users to communicate with thousands, possibly billions, of individuals around the world.

The crises have become a major feature of modern organizations in the presence of a complex and dynamic environment, where the existence of crises threatens the survival and growth of the organization and its ability to provide its products and services. Therefore, the crises affect its competitive position and reputation, when the organization is unable to deal with such crises through the presence of an efficient and effective management to manage the stages of the crisis, whether before it occurred or during its existence, or after its occurrence, and recovering from it.

Nowadays, and, in our current time, where an organization cannot escape from such crises, social media is considered as an effective aid in facing crises and adapting to changes, which are mostly unpredictable, because today's business environment is highly competitive. Hence, the organizations need to pay attention to their changing environment in order to develop and maintain. Besides, this necessity has become more decisive with the emergence of digital technologies, along with the importance of communication via social media, and the power of online communities in forming and influencing the reputation in the organization. Accordingly, the increasing capacity of media and communication channels has put the organizations in need of controlling the flow of information to enhance the effectiveness of organizational communication. While, social media can be considered as an effective tool for managing crises and anticipating difficult issues, social media helps the organization to invest its internal strengths through the speed of communication among its members, avoiding external threats, including crises, and placing them in a position where crises find an opportunity for change for the better and not a threat that would take them out of the work environment and end their existence, besides the availability of information and the speed of its spread throughout social media makes the organization or help it in discovering crises before they arise, and, hence developing the organization's readiness to face crises.

Crisis management has gained priority on policy agendas in many organizations. Such increase in the number of man-made and natural disasters has led the organizations to invest more in crisis management systems. Besides, the failure of crisis management leads to tragic consequences; significant property damage and human loss, as organizations operate in a dynamic and rapidly changing environment, which increases the uncertainty in the environment in which the organizations operate. Moreover, this leads to the possibility that these organizations will be exposed to crises that threaten their viability and growth (AlShibli, 2018).

It is worth stating that the inability of organizations to have appropriate tools and methods to assist them in forecasting that will help them and take over the sequence of changes that may occur in their environment may lead to exposure to many crises, meanwhile, the use of social media can be an effective tool for crisis management. Therefore, social media helps the organization in investing factors its internal strength is through the speed of communication between its individuals, employees, participants and customers, avoiding external threats including crises, and placing it in a position where crises find an opportunity for change towards the better and not a threat that would take them out of the work 
environment and end their existence (Bhaduri, 2019). Accordingly, this study problem can be identified with the following question:

What is the effect of using social media in crisis management from the point of view of workers in the National Emergency, Crisis and Disaster Management Authority in the United Arab Emirates?

\section{Use of Social Media}

It is worth stating that the development of information systems helped the emergence of social media platforms, as it became one of the most important resources or strategic factors that work to improve and succeed in organizations, and, it is considered as one of the main keys that contribute effectively to transforming inputs into outputs, and helps in the speed of completion of tasks, which serves the goals of the organizations and helps them survive, grow and achieve profits. So, its main goal is to develop techniques for use in planning, organizing and predicting the future and helping in managing crises to achieve the organization's goals (Manasir et al., 2019; obeidat, 2020). Over the past 20 years, the internet has become an essential part of many people's lives. Since 2005, the number of internet users worldwide has more than quadrupled from about one billion in 2005 to more than four billion in 2018 (Alkire et al., 2019; Malkawi, Baniata, \& Obeidat, 2017). In addition, more than half of the world's population now uses the internet. Not only has the number of internet users increased dramatically, but, the amount of time people spend on the internet has also increased. A survey of Global Webindex (2018) showed that the average internet user now spends about 6.2 hours per day using internet-based devices and services (Alkire et al., 2019). All companies that use the internet are service providers.

In this way, the internet has become a major actor in the economy, allowing current services (Such as retail, health care, and education) to be provided over the Internet, and to create new services and business models. One of the most important new services created by the Internet is social media (Such as Facebook and Twitter and Instagram). Through social media platforms, the total interaction between companies and customers, and between the customers themselves, is more than 3.3 billion users ((Statista, 2018). Therefore, the huge number of social media users, along with the accompanying data exchange, for example Facebook, generates up to 250 million shares per hour (Statista, 2018).

It is worth mentioning that social media refers to a group of online tools designed for social interaction, and, focuses on it. In practice, social media functions as a catch-all term for a range of web-based technologies and services such as blogging (like Twitter), besides social sharing services (Like YouTube, Flickr, Stumble Upon, and Last.fm), text messaging, discussion forums, collaborative editing tools (Like wikis), and virtual worlds, as well as social networking services (Such as Facebook and MySpace). These tools vary widely in their purposes and approaches, but, they share a common focus on enabling users to communicate, interact, edit and share content in a social environment (Unlu et al., 2010; Mahfodh, \& Obeidat ). On the other side, Kusumasondjaja (2018) defined social media as a set of internet-based application sources that provide information over the internet that is created, published and used by consumers to create, exchange and educate each other about products and brands available in the market and it is a communication mechanism that allows users to communicate with thousands, perhaps billions, of individuals worldwide. Kaplan and Haenlein (2010) define social media as a collection of internet-based applications that build on the technical foundations of Web 2.0 which allow the creation and sharing of usergenerated content. 
Hence, the presence of social media has brought a new set of models for various businesses, challenges the traditional process of business, and brings about major changes in communication and interaction between people, societies and organizations. For some organizations, social media works to transform previously irregular contact with clients into a stage. New from productive revenue to customers, organizations have taken a new form using social media applications, and markets for goods and services have transformed into a social sector and a user-driven market, as it has become a means to facilitate activities and relationships inside and outside the organization, social media can serve customers and business partners in developing joint products (Christofides et al., 2009). Furthermore, social media has become a strategic asset, as organizations that realize this fact are increasingly using social networking sites for recruitment purposes and employer branding (Dhir, 2016). However, it is time to move forward. Today, social media can be used to engage customers as well as internal stakeholders and employees. In addition, discussions about the pros and cons of using social media as an in-house tool in the workplace slowly fade away and social media continues to communicate smoothly in the workplace (Awad, 2014). With the rise of 2.0 Web, many companies have upgraded their intranets to "Social Intranets" by incorporating the features of Web 2.0. Apps like Facebook at Work, Microsoft Yammer, and IBM Connections help organizations create their own social networks. These private social networking tools - also called social media for organizations - usually offer network features similar to those found on public social networking sites. However, membership and access to these enterprise networks is restricted to the members of the organization within the boundaries of the organization itself (Sharma and Bhatnagar, 2016).

The organizations can use social media to measure the extent to which the organization meets customer needs. Also, the value of the successful integration of social media into the organizations will help improve and strengthen the relationships with internal and external stakeholders in a way that will benefit the ultimate base of the organization. For this reason, social media must be integrated into the organization's operations, and it cannot be a different entity of the organization, as it affects all the elements of the organization (Ernst et al., 2015).

\section{Crisis Management}

The environment of the organizations has become increasingly more complex and unstable which is represented by continuous development and changes, and, hence, exposes the organizations to a large number of crises (Sawalha et al., 2013,). This, of course, imposes on the organizations a set of challenges and obstacles, and, sometimes, leading to crises that differ in their causes and levels, as well as the severity of its impact on the organization, which constitutes a difficulty in its survival or growth and development (Abu Rumman, 2016). Therefore, this is what drives all the organizations to develop and improve their methods of crisis management in accordance with the requirements and conditions of the new work environment (Khaddam, 2014). Meanwhile, in the dynamic social and commercial environment, which is characterized by discontinuity and constant change, crises are understood as more than the rule rather than the exception in organizations. In addition, the number of disasters and accidents that cause the organizational crises has increased. The past twenty years alone have witnessed many catastrophic events, which have become an integral part of the psyche of society (Al Shobaki et al., 2016).

This has prompted the managers to consider the importance of proper crisis planning and management. However, and despite the magnitude of such events, they are only part of an 
increasingly complex set of factors that could be considered as significant potential threats to many companies, which also include data fraud, intellectual property theft and product liability, besides the normal commercial risks associated with doing business. (Heller and Darling, 2012; Irtaimeh et al., 2016)

Therefore, crisis management has never been more important. As recent events have shown, the business community, as well as societies in general, is vulnerable to disruptions that can be extremely costly. Examples of recent crises that have resulted in loss of lives, displaced families and communities, business closures, damaged economies, hurricanes, explosions and tsunamis in South Asia include the Coronavirus. Other dangerous events, such as financial failure from business mismanagement, workplace violence, fires, cybercrime, computer viruses, product tampering or union strikes, can also lead to significant damage and losses (Coombs, 2007; Al Thani\&obeidat, 2020). Whereas, effective crisis management provides an organized and regular response to crisis situations, this response model allows organizations to continue their day-to-day operations while managing a specific crisis. Moreover, the organized crisis management creates a system for early detection or warning (Joyner et al, 2013). Many crises can be prevented - or at least dealt with more effectively - with early detection. In addition, the company should utilize the expertise of the right individuals from various operational areas to plan and manage a crisis situation as it arises. Skills, constructive thinking, feeling energetic and engaged, knowing, acting responsibly, and confident in life processes can be of an immense value in effective corporate crisis leaders. Moreover, understanding and using these quantitative skills helps corporate crisis leaders to tackle issues creatively, giving them a deeper sense. Meaning, loyalty, and concern for the common public interest (Khaddam, 2014; Irtaimeh et al., 2016 ).

Many related studies have indicated several models in crisis management in order to be highly effective. But, they do not agree about what these stages are. Fink (1986) indicated that crises management goes through various stages starting from the warning stage, and finally the addiction stage. Meanwhile, other studies (Khaddam, 2014; El-Hamalawy 2003) see that crisis management goes through three stages, namely the pre-crisis period (Pre-crisis management period), the crisis management stage during the crisis, the crisis management stage Post-Crisis. Faulkner (2011) proposed a model consisting of five stages of crisis management, what the organization must work within each particular stage of the crisis, and the duties and tasks that must be worked out to be suitable for each stage. Accordingly, this provides the organization with the knowledge it needs in order to implement this task successfully. For the purposes of this study, these stages will be used as dimensions of crisis management, which are:

The Stage of Detection of Warning Signals: It refers to the stage before the onset of the crisis, and it is represented by the ability of the organization to respond to the warning signals that may cause the crisis which includes taking preventive measures that would prevent the occurrence of the crisis, or at least mitigate its severity and effects if it occurred despite the organization's efforts to prevent its occurrence and discovering early warnings of the occurrence of a crisis means discovering the crisis before it occurs, which will be a pleasure in preparing for it (Ahmed, 2010).

Preparedness and Prevention Stage: The organizations must at this stage create an emergency plan to confront the crisis, and form a crisis management team, who has previous experience in crisis management as possible. This stage also includes discovering the weak 
points in the organization and developing a plan to confront them, and identifying the necessary methods and tools necessary to help confronting the crisis, training employees on how to face crises, benefit from the lessons of others, develop information about crises and expected problems, and evaluate their degree of severity (Khaddam, 2014)

\section{The Crisis Containment Phase (harm containment)}

In this stage, a set of measures to be taken are defined, the communication processes are organized within the crisis field itself, the situation is stopped deteriorating, the losses are reduced, the psychological and social effects resulting from the crisis are addressed, and the practical performance is improved in a better way than before. Accordingly, the plans are carried out by implementing the decree to confront the crisis, and by using the organization's resources to reduce the crisis (Al-Mutairi, 2011; Al Qudah et al, 2020; Saffar \& Obeidat, 2020).

The Activity Recovery Stage: where the activity and operations of the organization are resumed, and the organization evaluates its loss and loss and assesses what is required in order to fully benefit from the activity and balance, human resources play an important role in this process, provided that human resources situation must be evaluated and what are the remaining capabilities of the organization, and what are the assets used and exploited after knowing the resources available so as to use them efficiently and effectively (Al-Khashali and Qutb, 2007; shrof et al, 2020).

The Learning Stage: Or the stage of drawing morals and lessons, and benefiting from the experience of dealing with the previous crisis to form experiences capable of avoiding crises, avoiding their recurrence, and standing at weaknesses, improving and avoiding them through the process of development and improvement (Bundy et al., 2017; Obeidat, \& Otibi, 2015).

\section{Study Approach}

This study is based on the use of a descriptive and analytical approach, which has been used to describe the variables for the study and measure the impact of using social networking sites in crisis management from the point of view of the workers in the National Emergency, Crisis and Disaster Management Authority in the United Arab Emirates, where the descriptive approach is based on data classification for description of the phenomenon of the study and its society through a field survey of the study sample consisting of employees of the National Authority for Emergency, Crisis and Disaster Management in the departments that depend on customs regulations. Furthermore, the researcher also collected the responses of the study sample individuals in order to test the hypotheses and present them in the form of tables and graphs, to arrive at the results of the study.

\section{Study Population and Sample}

The study population consisted of the employees of the National Authority for Emergency, Crisis and Disaster Management (750 employees). The analysis unit consisted of all employees at various administrative levels, and the authority showed cooperation in conducting scientific research.

The study adopted the sampling strategy, whereby a simple random sample was taken from all the employees working in the National Emergency and Crisis Management Authority, and Sekaran statistical tables were relied upon to determine the size of the acceptable sample, which amounted to (255) employees (Sekaran \& Bougie, 2010). But, the questionnaires on 
study sample individuals, retrieving (224) questionnaires, and (5) questionnaires were excluded for lack of completion, so that the researcher had (219) questionnaires valid for analysis, and a recovery rate of $(87.8 \%)$, which is a statistically acceptable rate. Table No. (1) below shows the characteristics of the study sample.

Table ( 1 ) Demographic data for response

\begin{tabular}{|l|l|l|l|}
\hline Variable & Category & Repetition & Percentage \\
\hline \multirow{4}{*}{ Gender } & Male & 132 & $60.3 \%$ \\
\cline { 2 - 4 } & Female & 87 & $39.7 \%$ \\
\cline { 2 - 4 } qualification & Total & 219 & 100.0 \\
\hline \multirow{5}{*}{ Experience } & High school & 23 & 10.5 \\
\cline { 2 - 4 } & Diploma & 17 & 7.6 \\
\cline { 2 - 4 } & Bachelor & 127 & $58 \%$ \\
\cline { 2 - 4 } & Postgraduate & 69 & $31.5 \%$ \\
\cline { 2 - 4 } & Total & 219 & 100.0 \\
\hline \multirow{5}{*}{ Position } & $0-5$ years & 43 & $19.6 \%$ \\
\cline { 2 - 4 } & $5-10$ years & 63 & $28.8 \%$ \\
\cline { 2 - 4 } & $10-15$ years & 87 & $39.7 \%$ \\
\cline { 2 - 4 } & $15+$ years & 26 & $11.9 \%$ \\
\cline { 2 - 4 } & Total & 219 & 100.0 \\
\hline & Top management & 26 & $28.3 \%$ \\
\cline { 2 - 4 } & Middle & 62 & $59.8 \%$ \\
\hline & management & & 100.0 \\
\cline { 2 - 4 } & Low management & 131 & \\
\cline { 2 - 4 } & Total & 219 & \\
\hline
\end{tabular}

\section{Test Validity and Reliability of the Study Tool}

The apparent validity of the questionnaire was tested by presenting it to the commission of experienced and specialized arbitrators from the academic professors, in order to express an opinion regarding it in terms of its suitability for collecting data related to the study, its clarity, coherence and cohesion, or any other remarks they deem appropriate regarding correction or deletion as deemed appropriate by the arbitrator. The arbitrators' comments and suggestions have been taken into consideration. Furthermore, the process of reviewing and auditing the questionnaire by the arbitrators, taking their observations and suggestions, in addition to making the modifications referred to by them was considered a test of the apparent validity of the tool. Therefore, the study tool is considered valid for measuring what it is designed for. Hence, the reliability of the instrument used in measuring the variables that it contains was also tested by using the Cronbach Alpha Coefficient test, where the result of the scale is statistically acceptable if the value of Cronbach Alpha is greater than (0.60) (Sekaran, 2006). Besides, the closer the value is to (100\%), this indicated higher stability scores for the study tool. In addition, by looking at the data presented in the following table, the Cronbach alpha internal consistency coefficient was measured for the study variables and its dimensions for the study tool as a whole so as to see the extent of consistency in the answers. This is shown as follows: 
Table (2): The values of the internal consistency coefficient for the study tool items

\begin{tabular}{|l|l|l|}
\hline Number & Dimension & Alpha value \\
\hline 1 & Publish information & 0.783 \\
\hline 2 & Access information & 0.737 \\
\hline 3 & Communicate with others & 0.816 \\
\hline 4 & Privacy and security & 0.824 \\
\hline Usage of social media & $\mathbf{0 . 9 2 4}$ \\
\hline 6 & Discover early warning signals & 0.708 \\
\hline 7 & Preparedness and prevention & 0.751 \\
\hline 8 & Containment of damages & 0.766 \\
\hline 9 & Restore activity & 0.665 \\
\hline 10 & Learning & 0.690 \\
\hline Crisis management & $\mathbf{0 . 9 2 2}$ \\
\hline All paragraphs & $\mathbf{0 . 9 1 8}$ \\
\hline
\end{tabular}

We note from Table (2) above that the values of the Cronbach internal consistency coefficient alpha for the paragraphs of the study tool ranged between $(0.665-0.824)$. In addition, the alpha value for all paragraphs reached (0.918). Therefore, all values are greater than $(0.60)$ and this is an indication of the consistency between the items of the study tool, and the reliability and credibility of the study tool for performing statistical analysis.

\section{Descriptive Statistics}

Independent Variable Analysis: Use of Social Media Sites

In order to describe the dimensions of the social media usage, arithmetic averages, the standard deviations were calculated to identify the level of social media usage in its dimensions, publishing information, accessing information, communicating with others, privacy and safety.

Table (3): The arithmetic averages of the responses of the study sample individuals regarding the level of social media usage

\begin{tabular}{||l|l|l|l|l|l|}
\hline Number & Dimension & $\begin{array}{l}\text { Arithmetic } \\
\text { mean }\end{array}$ & $\begin{array}{l}\text { Standard } \\
\text { deviation }\end{array}$ & arrangement & Level \\
\hline 1 & Publish information & 3.899 & 0.696 & 4 & High \\
\hline 2 & Access information & 3.937 & 0.694 & 2 & High \\
\hline 3 & $\begin{array}{l}\text { Communicate with } \\
\text { others }\end{array}$ & 3.951 & 0.803 & 1 & High \\
\hline 4 & Privacy and security & 3.904 & 0.762 & 3 & High \\
\hline & $\begin{array}{l}\text { General arithmetic } \\
\text { mean }\end{array}$ & 3.920 & 0.644 & & High \\
\hline
\end{tabular}

It is quite evident from Table (3) above that the arithmetic averages of the dimensions of the social media usage in the National Emergency Crisis and Disaster Management Authority ranged between $(3.951$ and 3,899$)$, where communication with others came on a total arithmetic average of (3.951), which is of a high level. The last one came after the information was published with an average of $(3,899)$, which is from the high level. 


\section{Dependent Variable}

\section{Analysis: Crisis Management}

In order to describe the dimensions of the dependent variable (Crisis management), the arithmetic averages and standard deviations were calculated to identify the level of all dimensions. Table (4) illustrates the matter:

Table (4): The arithmetic averages of the responses of the study sample individuals on the level of "crisis management".

\begin{tabular}{|l|l|l|l|l|l|}
\hline Number & Dimension & mean & S D & Arrangement & Level \\
\hline 1 & Discover early morning & 3.920 & 0.631 & 5 & High \\
\hline 2 & Preparedness and prevention & 3.942 & 0.647 & 4 & High \\
\hline 3 & Containment of damages & 4.112 & 0.640 & 1 & High \\
\hline 4 & Restore activity & 3.952 & 0.641 & 3 & High \\
\hline 5 & Learning & 4.059 & 0.602 & 2 & High \\
\hline & General arithmetic mean & $\mathbf{. 3 . 9 9 4}$ & $\mathbf{0 . 5 4 7}$ & & High \\
\hline
\end{tabular}

It is quite evident from Table (4) above that the arithmetic averages of the dimensions of crisis management in the National Emergency, Crisis and Disaster Management Authority came between (4.112 and 3.920), where the damage containment had the highest overall arithmetic average (4.112), with a high importance. Meanwhile, in the last place it came after the discovery of early warnings with a mean of (3.920), which is also of a high level.

\section{Testing the Hypotheses of the Study}

In this part of the study, we review the hypothesis testing, where the main hypothesis and its offshoots were subject to a Multiple Linear Regression.

H01: There is no statistically significant effect of the use of social media (Spreading information, accessing information, communicating with others, privacy and security) on detecting early warning signals

Table (5): * Results of the impact test after (Using social media) in detecting warning signals

\begin{tabular}{|c|c|c|c|c|c|c|c|c|c|c|}
\hline \multirow{2}{*}{$\begin{array}{l}\text { Depended } \\
\text { variable }\end{array}$} & \multicolumn{2}{|c|}{$\begin{array}{l}\text { Model } \\
\text { Summery }\end{array}$} & \multicolumn{3}{|c|}{ ANOVA } & \multicolumn{5}{|l|}{ Coefficients } \\
\hline & $R$ & R2 & $F$ & Df & Sig F* & Statement & B & Sd error & $T$ & Sig t* \\
\hline \multirow{4}{*}{$\begin{array}{l}\text { Discover } \\
\text { warning } \\
\text { signals }\end{array}$} & \multirow{4}{*}{0.340} & \multirow{4}{*}{0.116} & \multirow{4}{*}{7.004} & \multirow{4}{*}{4} & \multirow{4}{*}{0.000} & $\begin{array}{l}\text { Publish } \\
\text { informatio } \\
\text { n }\end{array}$ & 0.016 & 0.102 & 0.156 & 0.876 \\
\hline & & & & & & \begin{tabular}{|l|} 
Access \\
informatio \\
$n$
\end{tabular} & 0.211 & 0.090 & 2.355 & 0.019 \\
\hline & & & & & & $\begin{array}{l}\text { Communic } \\
\text { ate with } \\
\text { others } \\
\end{array}$ & $0.287-$ & 0.077 & 3.735- & 0.000 \\
\hline & & & & & & $\begin{array}{l}\text { Privacy and } \\
\text { security }\end{array}$ & 0.246 & 0.091 & 2.705 & 0.007 \\
\hline
\end{tabular}

- The effect is statistically significant at $(\alpha \leq 0.05)$. 
The results of Table No. (5) above shows that the correlation coefficient $(R=0.340)$ indicates the relationship between the independent variables and the dependent variable, Besides, the effect of the independent variables (Use of social media) on the dependent variable (Discovery of warning signals) is a statistically significant effect as the calculated $F$ value was (7.004), with a significant level of (Sig $=0.000)$, which is less than 0.05 , as it appeared. Therefore, the value of the coefficient of determination $(R 2=0.116)$ indicates that $(11.6 \%)$ of the variance in (Detection of alarm signals) can be explained during the contrast (Social media use) combined together.

On the other hand and as for the table of transactions, it showed that the value of (B) at the (Information dissemination) dimension reached (0.016) and that the value of $t$ was (0.156), and with a significance level ( $\mathrm{Sig}=0.876)$, indicate that the effect of this dimension is not significant. Meanwhile, the value of $B$ at the (Access to information) dimension, it reached (0.211) and that the value of $(T)$ was (2.355) with a significance level of (Sig $=0.019$ ), which indicates that the effect of this dimension is significant. The value of (B) reached at the (Communication level with others) to a dimension of $(0.287)$ and its $(T)$ value was $(-3.735)$, and a significance level of ( $\mathrm{Sig}=0.000$ ), which indicates that the effect of this dimension is significant. Moreover, the value of (B) was measured at the (Privacy and safety) dimension $(0.246)$ and its $(T)$ value was (2.705) with a significance level of (Sig $=0.007$ ), indicating that the effect of this dimension is significant.

H02: There is no statistically significant effect of using social media (Disseminating information, accessing information, communicating with others, privacy and security) on preparing and preventing to face crises.

Table (6): * Results of the post-impact test (For using social media) on preparation and prevention

\begin{tabular}{|c|c|c|c|c|c|c|c|c|c|c|}
\hline \multirow{2}{*}{$\begin{array}{l}\text { Depende } \\
\text { nt } \\
\text { variable }\end{array}$} & \multicolumn{2}{|c|}{$\begin{array}{l}\text { Model } \\
\text { Summery }\end{array}$} & \multicolumn{3}{|c|}{ ANOVA } & \multicolumn{5}{|c|}{ Coefficients } \\
\hline & $\mathrm{R}$ & R2 & $F$ & Df & Sig $F^{*}$ & $\begin{array}{l}\text { Statemen } \\
\mathrm{t}\end{array}$ & B & $\begin{array}{l}\text { Sd } \\
\text { error }\end{array}$ & $T$ & Sig t* \\
\hline \multirow{4}{*}{$\begin{array}{l}\text { Prepared } \\
\text { ness and } \\
\text { preventi } \\
\text { on }\end{array}$} & \multirow{4}{*}{0.215} & \multirow{4}{*}{0.046} & \multirow{4}{*}{2.604} & \multirow{4}{*}{4} & \multirow{4}{*}{0.037} & $\begin{array}{l}\text { Publish } \\
\text { informati } \\
\text { on }\end{array}$ & 0.001 & 0.109 & 0.008 & 0.993 \\
\hline & & & & & & $\begin{array}{l}\text { Access } \\
\text { informati } \\
\text { on } \\
\end{array}$ & 0.170 & 0.096 & 1.777 & 0.077 \\
\hline & & & & & & $\begin{array}{l}\text { Communi } \\
\text { cate with } \\
\text { others }\end{array}$ & $\begin{array}{l}0.159 \\
-\end{array}$ & 0.082 & 1.939- & 0.054 \\
\hline & & & & & & $\begin{array}{l}\text { Privacy } \\
\text { and } \\
\text { security }\end{array}$ & 0.129 & 0.097 & 1.332 & 0.184 \\
\hline
\end{tabular}

*The effect is statistically significant at $(\alpha \leq 0.05)$ 
It is worth stating that the results of Table No. (6) shows that the correlation coefficient $(R=$ $0.215)$, which indicates the relationship between the independent and dependent variables, and the effect of the independent variables of social media use on the dependent variable (Readiness and prevention) is a statistically significant effect, as the calculated (F) value was (2.604) with a significant level of (Sig $=0.037)$, which is less than 0.05 . This shows that the value of the coefficient of determination $(R 2=0.046)$ indicates that $(4.6 \%)$ of the variance in (Preparedness and prevention) can be explained by the variance in the use of methods Social communication combined.

As for the table of transactions, it showed that the value of (B) when the information was published reached (0.001). Meanwhile, the value of $(T)$ was $(0.008)$ with a significance level (Sig $=0.993$ ), indicates that the effect of this dimension is not significant. As for the value of (B) when reaching the information reached $(0.170)$ and that it's $(T)$ value is (1.777) with a significance level of (Sig $=0.077)$. This indicates that this dimension has a non-significant effect. Accordingly, the value of (B) when communicating with others was (-1.159) and its (T) value was $(-1.939)$ with a significance level of ( $\mathrm{Sig}=0.054)$ which indicates that the effect of this dimension is not significant. Hence, the value of (B) when the dimension of privacy and security is (0.129) and its ( $T$ ) value is (1.332), and its significance level is ( $\mathrm{Sig}=0.184)$. This means that this dimension is not significant.

H03: There is no statistically significant impact of the use of social media (Publishing information, accessing information, communicating with others, privacy and security) in containing the damages.

Table (7): * Results of the impact test (Using social media) in containing and reducing harm

\begin{tabular}{|c|c|c|c|c|c|c|c|c|c|c|}
\hline \multirow{2}{*}{$\begin{array}{l}\text { Dependent } \\
\text { variable }\end{array}$} & \multicolumn{2}{|c|}{$\begin{array}{l}\text { Model } \\
\text { Summery }\end{array}$} & \multicolumn{3}{|c|}{ ANOVA } & \multicolumn{5}{|c|}{ Coefficients } \\
\hline & $R$ & $\mathrm{R} 2$ & $F$ & Df & Sig $\mathrm{F}^{*}$ & $\begin{array}{l}\text { Statemen } \\
\mathrm{t}\end{array}$ & B & $\begin{array}{l}\text { Sd } \\
\text { error }\end{array}$ & $T$ & Sig $t^{*}$ \\
\hline \multirow{4}{*}{$\begin{array}{l}\text { Containme } \\
\text { nt of } \\
\text { damages }\end{array}$} & \multirow{4}{*}{0.280} & \multirow{4}{*}{0.078} & \multirow{4}{*}{4.537} & \multirow{4}{*}{4} & \multirow{4}{*}{0.002} & \begin{tabular}{|l} 
Publish \\
informati \\
on
\end{tabular} & 0.003 & 0.106 & 0.030 & 0.976 \\
\hline & & & & & & \begin{tabular}{|l} 
Access \\
informati \\
on \\
\end{tabular} & 0.086 & 0.093 & 0.926 & 0.355 \\
\hline & & & & & & $\begin{array}{l}\text { Communi } \\
\text { cate with } \\
\text { others } \\
\end{array}$ & $\begin{array}{l}0.114 \\
-\end{array}$ & 0.080 & -1.433 & 0.153 \\
\hline & & & & & & $\begin{array}{l}\text { Privacy } \\
\text { and } \\
\text { security }\end{array}$ & 0.249 & 0.094 & 2.643 & 0.009 \\
\hline
\end{tabular}

*The effect is statistically significant at $(\alpha \leq 0.05)$

The results of Table No. (7) herein above shows that the correlation coefficient $(R=0.280)$ indicates the relationship between the independent variables and the dependent variable, along with the effect of the independent variables using social media on the dependent variable (Damage Containment) is a statistically significant effect, where the value of (F) 
calculated (4.537) with a significance level of ( $\mathrm{Sig}=0.002)$, which is less than 0.05 . As shown, the value of the coefficient of determination $(R 2=0.078)$ indicates that $(07.8 \%)$ of the variance in (Damage Containment) can be explained by the variance in the use of the social media combined together.

The parameters table showed that the value of $(B)$ when the information was published reached $(0.003)$ and that the value of $(T)$ for it was $(0.030)$, in terms of (Sig $=0.976$ ), which indicates that the effect of this dimension is not significant. As for the value of (B) when reaching the information, it reached $(0.086)$ and that its $(T)$ value was $(0.926)$, with a significant level of ( $\mathrm{Sig}=0.355)$, which indicates that the effect of this dimension is not significant. Besides, the value of $B$ when communicating with others was $(-0.114)$ and its $(T)$ value was (-1.433). Therefore, with a significance level of (Sig $=0.153)$, it means that this dimension has an insignificant effect. The value of (B) when the privacy and security dimension is (0.249) and the (T) value for it is (2.643), and the level of significance is (Sig = $0.009)$. This means that this dimension has a significant effect.

H04: There is no statistically significant effect of the use of social media (Disseminating information, accessing information, communicating with others, privacy and security) in regaining activity.

Table (8): * Results of testing the effect of using social media in regaining activity

\begin{tabular}{|c|c|c|c|c|c|c|c|c|c|c|}
\hline \multirow{2}{*}{$\begin{array}{l}\text { Depende } \\
\text { nt } \\
\text { variable }\end{array}$} & \multicolumn{2}{|c|}{$\begin{array}{l}\text { Model } \\
\text { Summery }\end{array}$} & \multicolumn{3}{|c|}{ ANOVA } & \multicolumn{5}{|c|}{ Coefficients } \\
\hline & $R$ & R2 & $F$ & Df & Sig $\mathrm{F}^{*}$ & $\begin{array}{l}\text { Statemen } \\
\mathrm{t}\end{array}$ & B & $\begin{array}{l}\text { Sd } \\
\text { error }\end{array}$ & $T$ & Sig t* \\
\hline \multirow{4}{*}{$\begin{array}{l}\text { Restore } \\
\text { activity }\end{array}$} & \multirow{4}{*}{0.214} & \multirow{4}{*}{0.046} & \multirow{4}{*}{2.568} & \multirow{4}{*}{4} & \multirow{4}{*}{0.039} & $\begin{array}{l}\text { Publish } \\
\text { informati } \\
\text { on }\end{array}$ & 0.291 & 0.108 & -0.408 & 0.684 \\
\hline & & & & & & $\begin{array}{l}\text { Access } \\
\text { informati } \\
\text { on }\end{array}$ & 0.150 & 0.095 & 0.727 & 0.468 \\
\hline & & & & & & $\begin{array}{l}\text { Communi } \\
\text { cate with } \\
\text { others }\end{array}$ & 0.387 & 0.081 & -1.617 & 0.107 \\
\hline & & & & & & $\begin{array}{l}\text { Privacy } \\
\text { and } \\
\text { security }\end{array}$ & 0.019 & 0.096 & 2.461 & 0.015 \\
\hline
\end{tabular}

*The effect is statistically significant at ( $\alpha \leq 0.05)$.

The results of Table No. (8) above shows that the correlation coefficient $(R=0.214)$ indicates the relationship between the independent variables and the dependent variable, along with the effect of the independent variables and social media on the dependent variable (Activity recovery) is a statistically significant effect, especially as the calculated (F) value was (2.568) with a significant level of ( $\mathrm{Sig}=0.039)$, which is less than 0.05. Therefore, it clear that the value of the coefficient of determination at $(R 2=0.046)$ indicates that $(04.6 \%)$ of the variance 
in (Recovery of activity) can be explained by the variance in the communication of social media combined. together

As for the table of transactions, it is shown that the value of (B) when the information was published reached $(0.291)$ and that the value of $(T)$ was $(-0.408)$ with a significance level (Sig $=0.684)$, which indicates that the effect of this dimension is not significant. But, as for the value of $(B)$ when coming to the information, it reached $(0.150)$ and that its $(T)$ value is $(0.727)$ with a significant level of (Sig $=0.468)$, which indicates that the effect of this dimension is not significant. Accordingly, the value of (B) when communicating with others was $(0.387)$ and its $(\mathrm{T})$ value was $(-1.617)$ with a significance level $(\mathrm{Sig}=0.107)$, which indicates that the effect of this dimension is not significant. Besides, the value of (B) was measured the privacy and security dimension (0.019) and the $(T)$ value for it was (2.461), with a significance level of (Sig $=0.015)$, which indicate that the effect of this dimension is significant.

H05: There is no statistically significant effect of social media use (spreading information, accessing information, communicating with others, privacy and security) on learning from crises.

Table (9): * Results of testing the effect of using social media on learning.

\begin{tabular}{|c|c|c|c|c|c|c|c|c|c|c|}
\hline \multirow{2}{*}{$\begin{array}{l}\text { Depende } \\
\text { nt } \\
\text { variable }\end{array}$} & \multicolumn{2}{|c|}{$\begin{array}{l}\text { Model } \\
\text { Summery }\end{array}$} & \multicolumn{3}{|c|}{ ANOVA } & \multicolumn{5}{|l|}{ Coefficients } \\
\hline & $R$ & $\mathrm{R} 2$ & $F$ & Df & Sig F* & Statement & B & Sd error & $T$ & Sig t* \\
\hline \multirow{4}{*}{ Learning } & \multirow{4}{*}{0.258} & \multirow{4}{*}{0.067} & \multirow{4}{*}{3.812} & \multirow{4}{*}{4} & \multirow{4}{*}{0.005} & $\begin{array}{l}\text { Publish } \\
\text { information }\end{array}$ & $\begin{array}{l}0.011 \\
-\end{array}$ & 0.100 & $\begin{array}{l}- \\
0.109\end{array}$ & 0.913 \\
\hline & & & & & & $\begin{array}{l}\text { Access } \\
\text { information }\end{array}$ & 0.007 & 0.088 & 0.076 & 0.939 \\
\hline & & & & & & $\begin{array}{l}\text { Communicate } \\
\text { with others }\end{array}$ & $\begin{array}{l}0.154 \\
-\end{array}$ & 0.076 & - & 0.042 \\
\hline & & & & & & $\begin{array}{ll}\text { Privacy } & \text { and } \\
\text { security } & \end{array}$ & 0.290 & 0.089 & 3.253 & 0.001 \\
\hline
\end{tabular}

*The effect is statistically significant at ( $\alpha \leq 0.05)$.

Table No. (9) above of the correlation coefficient $(R=0.258)$ indicates that the relationship between the independent variables and the dependent variable, besides the effect of the independent variables of social media use on the dependent variable (Learning) is of a statistically significant effect, especially as the calculated (F) value was (3.812) ) with a significance level ( $\mathrm{Sig}=0.005)$, which is less than 0.05 , as it appeared that the value of the coefficient of determination ( $R 2=0.067$ ) indicates that $(06.7 \%)$ of the variance in (Learning) can be explained by the variance in social media usage combined together.

The coefficients showed that the value of (B) when the information was published reached (0.011 ) and that the value of $(T)$ was $(-1.109)$ with a significance level of (Sig $=0.913)$. This means that this dimension has a non-significant effect. As for the value of (B) when reaching the information, it reached (0.007), besides, the value of $(T)$ for it was (0.076) with a significant level of (Sig $=0.939)$. This means that this dimension has an insignificant effect. 
Accordingly, the value of (B) when communicating with others was (0.154) and its $(T)$ value was $(-2.044)$ with a significance level of $(\mathrm{Sig}=0.042)$, which means that this dimension has a significant effect. Hence, the value of (B) when the dimension of privacy and security is $(0.290)$ and its $(T)$ value is (3.253), its significance level is ( $\mathrm{Sig}=0.001)$. This means that this dimension has a significant effect.

\section{Results}

This study is aimed at finding out the effect of using social media sites on crisis management in the National Emergency, Crisis and Disaster Management Authority in the United Arab Emirates, where the results of the descriptive census showed the high relative importance of using social media sites in the authority. Therefore, this indicates the authority's keenness to use all technologies and the means to keep pace with modern technology. In addition, the results also showed the high relative importance of crisis management in the authority, which this indicates the broad interest by the authority to manage crises in the country in all its forms. As for the results of the hypothesis testing, the results showed an impact of the use of social media sites in all stages of crisis management. Accordingly, this result is consistent with a study (Khaddam, 2014), which found an impact of information systems in all stages of crisis management. The real challenge is not only to acknowledge the crises, but also to identify them in a timely and willing manner to address the issues they pose. What are the early warning signs? What analyzes provide early warning of change and the potential for a future institutional crisis? Once again, the challenge is not only to acknowledge the crisis, but, also, to focus on the complex factors in a way that corporate leaders can understand and organize the forces needed to address the situation (Zwelff, 2016). Moreover, it is important for the authority and in order to continue the survival of organizations including the National Emergency, Crisis and Disaster Management Authority in the United Arab Emirates "In a stable and controlled situation to conduct an environmental survey (The external environment and the internal environment) periodically and regularly, so as to identify the indicators of the occurrence of crises, and focus on the (Lessons learned) from the crisis after at the end, and document the same as previous experiences by using methods (scenarios) for preparing prior solutions to confront the expected crisis.

\section{References}

Ahmed, H. O. (2010) The Impact of Information Quality on Crisis Management A Field Studies of a Sample of Civil Telecommunications Companies in Somalia. Unpublished MA Thesis, University of Aden, Yemen.

Al Shobaki, M., Abu Amuna, Y., \& Badah, W. (2016). The Impact of the Strategic Orientations on Crisis Management Agency, International Relief in Gaza, First Scientific Conference for Community Development 5-6 November, 2016.

Al Thani, F. B. H., \& Obeidat, A. M. (2020). The Impact of Strategic Leadership on Crisis Management. International Journal of Asian Social Science, 10(6), 307-326.

Alkire, L., Pohlmann, J., \& Barnett, W. (2019). Triggers and Motivators of Privacy Protection Behavior on Facebook", Journal of Services Marketing, 33 (1) 57-72.

Al-Mutairi, F. (2011). The Effect of Using Strategic Planning Methods on Crisis Management in the Kuwaiti Islamic Banking Sector, Master Thesis, Middle East University, jordan

Al-Qudah, S., Obeidat, A. M., \& Shrouf, H. (2020). The impact of strategic human resources planning on the organizational performance of public shareholding companies in Jordan. Problems and Perspectives in Management, 18(1), 219. 
Al-Shibli, B. (2018). The Impact of Information Technology Capabilities on Crisis Management: A Field Study on the Jordanian Commercial Banking Sector, Unpublished Master Thesis, Middle East University, Amman, Jordan

Bhaduri, R. M. (2019), Leveraging culture and Leadership in Crisis Management, European Journal of Training and Development, 43 ( 5) 554-569.

Bundy, J., Pfarrer, M. D., Short, C. E., \& Coombs, W. T. (2017). Crises and crisis management: Integration, interpretation, and research development. Journal of Management, 43(6).

Christofides, E., Muise, A., and Desmarais, S. (2009), "Information Disclosure and Control on Facebook: Are They Two Sides of the Same coin or two different processes, Cyberpsychology \& Behavior, 12 ( 3) 341-345.

Coombs, W. T. (2007), Ongoing Crisis Communication: Planning, Managing, and Responding, Thousand Oaks, CA

Darwish, S., Ahmed, U., \& Pahi, M. H. (2020). Innovative Work Behavior During COVID-19 for Medical Representative in the Pharmaceutical Industry: Test of a Moderation Model in Bahrain. International Journal of Pharmaceutical Research. 12(4), 19271934. doi.org/10.31838/ijpr/2020.12.04.277

Faulkner, B. (2001). Towards a framework for tourism disaster management, Tourism

Fink, S. (1986), Corporate Crisis Leaders: Planning for the Inevitable, American Corporate Leaders Association, New York, NY.

Heller, V. L., \& Darling, J. R. (2012). Anatomy of crisis management: lessons from the infamous Toyota Case. European Business Review, 24 (2), 151-168.

Irtaimeh, H. J., Obaidat, A., \& Khaddam, A. (2016). Strategic Role of Dashboard Application in Enhancing Crisis Management Capabilities in Organizations Field Study on Jordanian Cellular Companies. International Journal of Management Sciences and Business Research.5(10)50-59

Irtaimeh, H. J., Obeidat, A. M., Abualloush, S. H., \& Khaddam, A. A. (2016). Impact of business intelligence on technical creativity: A case study on AlHekma Pharmaceutical Company. European Scientific Journal, 12(28), 502-519.

Joyner, F. F., Frantz, D., and Maguire, L. (2013), "When culture saved the day: organization culture and crisis management", Journal of Business Case Studies (Jbcs), 9 ( 2) 165-174

Kaplan, A. M., and Haenlein, M. (2010), "Users of the world, unite! The challenges and opportunities of social media", Business Horizons, 53 (1) 59-68.

Khaddam, A. (2014). Integration of Management Information Systems and Knowledge Sharing and their Role in Crisis Management (A field study in Jordanian cellular telecommunications companies), unpublished PhD thesis, Jinan University, Lebanon.

Kusumasondjaja, S. (2018), "The roles of message appeals and orientation on social media brand communication effectiveness: An evidence from Indonesia", Asia Pacific Journal of Marketing and Logistics, 30 ( 4) 1135-1158

Mahfodh, A. B. S. B., \& Obeidat, A. M. (2020). Knowledge Sharing Tools and their Impact on Enhancing Organizational Performance. International Journal of Academic Research in Business and Social Sciences. 10(9), 91-112.

Malkawi, N. M., Baniata, M. I., \& Obeidat, A. M. (2017). The Impact of E-Government Applications on Decision-Making Effectiveness: Case Study at Jordanian Ministry of Interior-Jordan. International Review of Management and Business Research, 6(1), 172.

Obeidat, A. (2019). IT Adaption with Knowledge Conversion Process (SECI)?. Management Science Letters, 9(13), 2241-2252. 
Obeidat, A. M., \& Otibi, G. A. (2015). The impact of knowledge sharing tools on levels of organizational learning (Field Study on Jordanian Commercial Banks). Australian Journal of Basic and Applied Sciences, 9(5), 253-267.

Saffar, N., \& Obeidat, A. (2020). The effect of total quality management practices on employee performance: The moderating role of knowledge sharing. Management Science Letters, 10(1), 77-90.

Sawalha, H. I., Eid Jraisat, L., \& Al-Qudah, K. A. M. (2013). Crisis and disaster management in Jordanian Hotels: Practices and Cultural Considerations", Disaster Prevention and Management, 22 ( 3) 210-228

Shrouf, H., Al-Qudah, S., Khawaldeh, K., Obeidat, A., \& Rawashdeh, A. (2020). A study on relationship between human resources and strategic performance: The mediating role of productivity. Management Science Letters, 10(13), 3189-3196.

Statista. (2018). Global Digital Population as of July 2018 (in millions)", available at: www.statista.com/statistics/617136/ digital-population-worldwide/ (accessed 1 October 2018).

Unlu, A., Kapucu, N., and Sahin, B. (2010), "Disaster and crisis management in Turkey: a need for a unified crisis management system", Disaster Prevention and Management, 19 ( 2) 155-174. 